Joanna CZARNOCKA

Urszula ZBOROWSKA

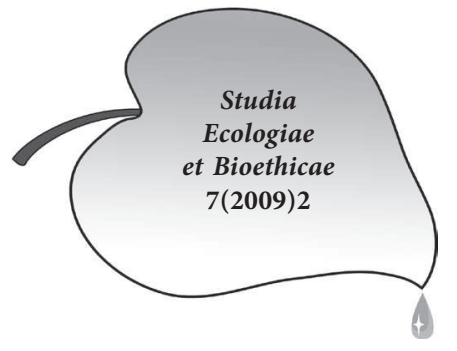

Instytut Paliw i Energii Odnawialnej Warszawa

\title{
Ekonomiczne i ekologiczne aspekty stosowania systemu znakowania paliw akcyzowych
}

\section{Podstawowe definicje}

Znacznik jest to substancja chemiczna, która jest wprowadzana do danego produktu naftowego w celu oznakowania go w sposób niewidoczny dla ludzkiego oka. Znacznik nie zmienia naturalnej barwy paliwa i jest wykrywany za pomocą prostego testu chemicznego. Ma stanowić „ukryty” dowód na to, że paliwo jest wykorzystywane zgodnie lub niezgodnie z przeznaczeniem.

Barwnik to substancja chemiczna, która jest dodawana do danego produktu paliwowego w celu jego wizualnego wyróżnienia szczególnie wtedy, gdy paliwa mają zbliżone właściwości fizykochemiczne. Barwnik nadaje paliwom żądaną barwę, np. czerwoną, zieloną i daje użytkownikowi informację o tym, jaki rodzaj paliwa stosuje.

\section{Idea wprowadzenia znacznika i barwnika do paliw}

System podatkowy jest czynnikiem, który zapewnia odpowiednie wpływy środków finansowych do budżetu i umożliwia prawidłowe funkcjonowanie państwa. W celu zwiększenia dochodów budżetowych niektóre wyroby podlegają opodatkowaniu akcyzą. Akcyza jest podatkiem pośrednim, ponieważ nie jest płacony w urzędzie skarbowym, ale dopiero przy nabywaniu danego wyrobu lub usługi i jest kosztem ponoszonym przez finalnego nabywcę. Wyroby, które podlegają opodatkowaniu akcyzą to np. produkty energetyczne stosowane do celów napędowych i grzewczych, alkohole, wyroby tytoniowe. W celu wspomożenia funkcjonowania danego sektora gospodarki kraju polityka ekonomiczna państwa dopuszcza możliwość stosowania odpowiednich zwolnień od akcyzy lub obniżenia jej stawek.

W krajach Unii Europejskiej obowiązują wspólne zasady produkcji, przemieszczania i przechowywania wyrobów akcyzowych oraz wymiaru i sposobu 
poboru podatku. Stawki akcyzy na poszczególne wyroby są określane indywidualnie przez Państwa Członkowskie, ale nie mogą być niższe niż ustalone w dyrektywach. W Polsce wspólne zasady opodatkowania obowiązują od 1 maja $2004 \mathrm{r}$.

Pewne wyroby akcyzowe muszą być oznakowane specjalnymi znakami akcyzy - banderolami. Tak dzieje się w przypadku wyrobów tytoniowych i alkoholowych. Dla paliw nie można zastosować typowego znaku akcyzy, czyli papierowej banderoli, trzeba posłużyć się innym wyróżnikiem. Takim wyróżnikiem jest właśnie znacznik, czyli płynna substancja chemiczna wprowadzana do paliwa, która nie zmienia jego naturalnej barwy, a może być wykryta za pomocą prostego testu polowego. Testem takim mogą posługiwać się pracownicy policji, celnicy i służby skarbowe.

\section{Znakowanie i barwienie paliw akcyzowych w świetle polskich i europejskich unormowań prawnych}

Pierwsza decyzja w sprawie ustanowienia wspólnych reguł znakowania paliw została zapisana w Dyrektywie Rady Państw Unii Europejskiej 95/60/WE z dnia 27.11.1995 r. Dyrektywa wprowadzała możliwość znakowania olejów napędowych i nafty, nie określała jednak nazwy związku chemicznego, który mógłby być użyty jako znacznik. Znacznik miał być wybrany dopiero po przeprowadzeniu niezbędnych badań. Podczas dokonywania wyboru produktu brane były pod uwagę takie właściwości jak rozpuszczalność w produktach naftowych, stabilność fizyczna i chemiczna, wpływ na zdrowie i środowisko, odporność na usuwanie oraz koszt metod wykrywania. Badania przeprowadzone były we Wspólnym Ośrodku Badawczym Komisji Europejskiej i w 14 laboratoriach Państw Członkowskich UE. Spośród kilku testowanych substancji najlepszą opinię otrzymał Solvent Yellow 124 i to właśnie on został ustanowiony decyzją Komisji Europejskiej 2001/574/WE z dnia 13.02.2001 r. wspólnym znacznikiem skarbowym. Decyzja ta podawała, że Solvent Yellow 124 (SY 124) będzie wprowadzony do użytkowania od 1 sierpnia 2002 r., a poziom znakowania ustaliła na nie mniejszy niż $6 \mathrm{mg} / \mathrm{l}$. Solvent Yellow 124 jest powszechnie określany nazwą euromarker.

Planowane przeglądy powyższych unormowań prawnych doprowadziły do wydania kolejnej decyzji 2003/900/WE z dnia 17.12.2003 r., która określiła maksymalny poziom znakowania paliwa na $9 \mathrm{mg} / \mathrm{l}$, argumentując swoje postanowienie potrzebą policzenia fałszywych użyć oznakowanych paliw. Ostatnia decyzja - 2006/428/WE z 22.06.2006 r. wydana po następnych konsultacjach, przeprowadzonych w Państwach Członkowskich, podtrzymała wcześniejsze ustalenia.

Państwa Członkowskie mogą stosować własne systemy barwnego wyróżniania produktów akcyzowych i nie ma tu unijnych unormowań prawnych. Rodzaj 
Ekonomiczne i ekologiczne aspekty stosowania systemu znakowania paliw akcyzowych

i ilość barwnika podana jest w przepisach danego kraju. W tabeli 1 przedstawiono barwniki stosowane w wybranych krajach Unii Europejskiej.

Tabela 1. Barwniki wykorzystywane do barwienia paliw akcyzowych w 14 krajach Unii Europejskiej od sierpnia 2002 roku. Zawartość euromarkera - $6 \mathrm{mg} / \mathrm{ll}^{1)}$

\begin{tabular}{|c|c|c|c|}
\hline Kraj & $\begin{array}{c}\text { Barwiony } \\
\text { produkt }\end{array}$ & $\begin{array}{c}\text { Nazwa } \\
\text { barwnika }\end{array}$ & $\begin{array}{c}\text { Zawartość barwnika } \\
\text { w produkcie }\end{array}$ \\
\hline Austria & olej napędowy & czerwony barwnik & widzialny \\
\hline Belgia & olej opałowy & czerwony barwnik & widzialny \\
\hline Dania & olej napędowy & Solvent Blue 35 & $5 \mathrm{mg} / \mathrm{l}$ \\
\hline Finlandia & olej napędowy & Solvent Red 19 & $3 \mathrm{mg} / \mathrm{l}$ \\
\hline Francja & $\begin{array}{c}\text { olej napędowy } \\
\text { paliwo żeglugowe }\end{array}$ & $\begin{array}{c}\text { Solvent Red } 24 \\
\text { Solvent Blue } 35\end{array}$ & $10 \mathrm{mg} / \mathrm{l}$ \\
$10 \mathrm{mg} / \mathrm{l}$
\end{tabular}

W Polsce pierwsze rozporządzenie odnoszące się do identyfikowania paliw akcyzowych dotyczyło barwienia na czerwono olejów przeznaczonych na cele opałowe i ukazało się w sierpniu 1998 r. We wrześniu 1999 r. został wprowadzony obowiązek znakowania wybranego rodzaju paliwa euromarkerem. Obowiązek ten dotyczył paliwa wykorzystywanego do celów opałowych, dopiero w późniejszych latach wprowadzono do systemu znakowania paliwa żeglugowe.

Kolejne rozporządzenia wprowadziły do barwienia oleju opałowego dwa barwniki Solvent Red 164 i Solvent Red 19, a dla paliwa żeglugowego Solvent Blue 35. Ilość znacznika Solvent Yellow 124 została dostosowana do wymagań Unii rozporządzeniem Ministra Finansów z dnia 12.02.2009 r. ${ }^{2}{ }^{2}$ i obecnie zawiera się w granicach 6-9 mg/l, natomiast, jak już wspomniano wcześniej, rodzaj i ilość barwnika jest indywidualną sprawą danego państwa. Polska będąc członkiem UE może aktywnie uczestniczyć w kolejnych przeglądach i weryfikacjach decyzji Wspólnoty Europejskiej w tej dziedzinie. 


\section{Ekonomiczne i ekologiczne aspekty regulacji podatkowych}

1 marca 2009 r. weszła w życie ustawa $\mathrm{z}$ dnia 6 grudnia 2008 r. o podatku akcyzowym ${ }^{3)}$, która reguluje ogół spraw związanych z opodatkowaniem, klasyfikowaniem i sposobem wprowadzania do obrotu wyrobów akcyzowych.

W myśl tej ustawy wyroby akcyzowe wykorzystywane do celów żeglugi są zwolnione z podatku akcyzowego, a wyroby akcyzowe stosowane do celów opałowych obłożone są niższą stawką podatku niż zbliżone jakościowo oleje napędowe. Każdy wyrób akcyzowy ma przypisany swój kod CN (Nomenklatura Scalona), a tym samym określoną stawkę podatku. I tak na przykład oleje napędowe przeznaczone do celów opałowych mają stawkę podatku - 232,00 zł za 1000 litrów (pod warunkiem, że są zabarwione na czerwono i oznaczone znacznikiem SY 124), natomiast oleje napędowe przeznaczone do celów napędowych - 1048,00 zł za 1000 litrów. Różnica w stawce podatku jest więc 4,5 krotna.

Podobnie przedstawia się sytuacja w przypadku olejów opałowych, chociaż tu ustawodawca poza kodami CN i znacznikiem oraz barwnikiem nałożył jeszcze dodatkowe obwarowania tzn. próg destylacji i gęstości (30\% lub więcej objętościowo destyluje przy $350^{\circ} \mathrm{C}$ lub których gęstość $\mathrm{w} 15^{\circ} \mathrm{C}$ jest niższa niż 890 $\mathrm{kg} / \mathrm{m}^{3}$ ). Oleje spełniające wcześniej wymienione warunki podlegają stawce podatku 232,00 zł/1000 l, pozostałe oleje opałowe 60,00 zł/ 10001.

Ustawodawca wprowadzając takie stawki podatku kierował się kilkoma celami. W przypadku stosowania oleju napędowego do zasilania silników pojazdów samochodowych mamy do czynienia tylko i wyłącznie z celem ekonomicznym, czyli zasileniem budżetu państwa. W przypadku oleju napędowego wykorzystywanego do celów grzewczych lub oleju opałowego lekkiego wyraźnie rysuje się cel ekologiczny tzn. chęć promowania do zasilania przydomowych instalacji grzewczych, paliwa o niskiej zawartości siarki. Należy tutaj nadmienić, że przez wiele lat węgiel kamienny był tradycyjnym paliwem grzewczym dla przemysłowych i indywidualnych użytkowników ciepła. Płynne paliwa niskosiarkowe dały możliwość wprowadzenia na rynek produktu emitującego podczas spalania mniejszą ilość zanieczyszczeń niż węgiel kamienny czy brunatny.

Jeszcze kilka lat temu oleje napędowe charakteryzowały się zawartością siarki na poziomie $0,035 \%$ mas., obecnie mają jej 0,001\% mas. Zawartość siarki w lekkich olejach opałowych nie powinna przekraczać $0,1 \%$ mas., a w olejach ciężkich - $1 \%$ mas. Ze względów technologicznych nie jest możliwe, aby wszystkie produkowane paliwa były niskosiarkowe. Jednak dąży się do tego, aby w powszechnym użyciu były produkty zawierające jak najmniej siarki, co widać wyraźnie w zastosowanych regulacjach podatkowych. Lekki olej opałowy lub olej napędowy stosowany do celów grzewczych jest 4,5 krotnie tańszy niż olej napędowy do zasilania silników samochodowych. 
Stosując zwolnienia od podatku akcyzowego dla paliw żeglugowych, ustawodawca wprowadził narzędzie wsparcia dla danego sektora gospodarki, w tym przypadku rybołówstwa.

Tak duże różnice w stawce podatku akcyzowego między olejem napędowym a lekkim olejem opałowym, czy też paliwem żeglugowym mogą stanowić czynnik do nadużyć finansowych. Często spotyka się przypadki zasilania samochodów z silnikiem wysokoprężnym mieszaniną oleju napędowego i lekkiego oleju opałowego lub paliwa żeglugowego. Każde użycie lekkiego oleju opałowego i paliwa żeglugowego w celu zasilania silnika samochodowego jest więc „wykroczeniem” podatkowym. Ustawodawca dysponuje odpowiednimi służbami uprawnionymi do kontroli rodzaju paliwa np. na stacjach paliw, czy w bakach samochodowych. Właściciel lub kierowca skontrolowanego pojazdu, w którego paliwie zostanie wykryty znacznik Solvent Yellow 124 musi zapłacić karę oraz dopłacić różnicę w podatku akcyzowym.

Jak już wcześniej wspomniano, znacznik SY 124 i barwniki (czerwony dla oleju opałowego, a niebieski dla paliwa żeglugowego) stanowią swoisty wyróżnik danego produktu. Znacznik i barwniki są zabezpieczeniem przed nieprawidłowym wykorzystywaniem lekkiego oleju opałowego bądź paliwa żeglugowego i czerpaniem nieuzasadnionych zysków ze sprzedaży paliwa obłożonego niższym podatkiem akcyzowym jako paliwa droższego.

Wprowadzony przez kraje europejskie system identyfikowania wybranych gatunków paliw przyczynia się do uporządkowania rynku paliw ograniczając „szarą strefę”, wpływa na poprawę sytuacji budżetu państwa. Jest narzędziem pozwalającym ustawodawcy kontrolować prawidłowość użycia danego rodzaju paliwa, a przede wszystkim zapobiegać nadużyciom.

\section{Literatura}

1. Rudd A., Marking of Fuel - The EU Makes Slow Progress, European Refining \& Marketing, 2002.

2. Dziennik Ustaw z 2009 r., nr 32, poz. 218.

3. Dziennik Ustaw z 2009 r., nr 3, poz. 11. 


\section{Economical and ecological aspects of excise fuels markers system application}

\section{SUMMARY}

This article describes different aspects of tax exemption and fiscal relief for liquid fuels. The common marking system to identify tax fuels was introduced by Directive 95/60/EC. It was explained the aim and the principle of functioning the system of identyfication of marker fuels. 